\title{
Arbuscular Mycorrhizal Colonization Increased Above- Belowground Feedback of Maize In a Degraded Coal Mining Area Soil By Increasing The Photosynthetic Carbon Assimilation And Allocation of Mazie
}

Yinli Bi ( $\square$ ylbi88@126.com)

China University of Mining and Technology-Beijing https://orcid.org/0000-0002-5562-1045

\section{Xiao Wang}

China University of Mining and Technology Beijing Campus

Yun Cai

China University of Mining and Technology Beijing Campus

Peter Christie

Xi'an University of Science and Technology

\section{Research Article}

Keywords: AM fungi, carbon allocation, positive feedback, stress resistance, soil carbon content, $13 \mathrm{CO} 2$ pulse labeling

Posted Date: November 19th, 2021

DOI: https://doi.org/10.21203/rs.3.rs-993769/v1

License: (a) (1) This work is licensed under a Creative Commons Attribution 4.0 International License. Read Full License 


\section{Abstract}

A three-compartment culture system was used to study the mechanism by which the AM fungus Funneliformis mosseae influences host plant growth and soil organic carbon (SOC) content in a coal mining area. $\mathrm{A}^{13} \mathrm{CO}_{2}$ pulse tracing technique traced the allocation of maize photosynthetic $\mathrm{C}$ in shoots, roots, $\mathrm{AM}$ fungus and soil to detect $\mathrm{C}$ accumulation and allocation in mycorrhizal (inoculated with Funneliformis mosseae) and non-mycorrhizal treatments.AM fungal inoculation significantly increased the ${ }^{13} \mathrm{C}$ concentration and content in both above- and below-ground plant parts. Mycorrhizal inoculation significantly enhanced the anti-aging ability by increasing soluble sugars and catalase activity (CAT) in maize leaves while reducing foliar malondialdehyde content (MDA) and leaf temperature to promote plant growth. AM fungi also increased P uptake to promote maize growth. Soil organic carbon (SOC), glomalin, microbial biomass carbon (MBC) and nitrogen (MBN) contents increased significantly after inoculation. A mutually beneficial system was established involving maize, the AM fungus and the microbiome, and the AM fungus became an important regulator of $\mathrm{C}$ flux between the above- and below-ground parts of the system. Inoculation with the AM fungus promoted plant growth, $\mathrm{C}$ fixation and allocation belowground to enhance soil quality. The positive above-belowground feedback appeared to be established.

\section{Introduction}

In a natural system there is positive above-belowground feedback that is essential for a healthy ecosystem (Mariotte et al. 2018). However, some artificial practices such as coal mining disrupt this and lead to environmental degradation (Rocha-Nicoleite et al. 2017). It is therefore important to devise methods for the ecological restoration of mining areas (De and Mitra 2002; Shrestha and Lal 2006). Inoculation with arbuscular mycorrhizal fungi has been demonstrated to be an effective biotic method to achieve ecological restoration of degraded mining areas (Bi et al. 2018 and 2019; Vahter et al. 2020; Wang 2017). However, how the AM fungal inoculation influences the positive above-belowground feedback of mining areas remains unclear. The soil organic carbon (SOC) pool is an important part of soil fertility, productivity and quality (Schlesinger 1999; Wiesmeier et al. 2019). Changes in SOC are considered an indicator of feedback effects (Kirschbaum 2000; Liu et al. 2019). Carbon is derived mainly from the primary net productivity of higher plants and the allocation of photosynthates belowground (Malhi et al. 2011). A large portion of the $C$ fixed by photosynthesis is distributed directly to plant roots and root-associated soil microorganisms which indirectly affect soil C sequestration (Zhu and Miller 2003; Heinemeyer et al. 2007; Dijkstra and Cheng 2007). Microbially mediated plant-soil feedback affects plant growth and community assembly (van der Heijden et al. 1998; Kardol et al. 2007). Arbuscular mycorrhizal (AM) fungi can form a potentially symbiotic mutual association with the roots of $80 \%$ of terrestrial plant species, accelerate the growth of host plants, and promote plant photosynthetic $\mathrm{C}$ fixation (Rodrigues and Rodrigues 2014) through enhancing nutrition uptake, water supply and C source-sink relations (Bethlenfalvay et al. 1982 and 1988; Andrade et al. 1998; Black et al. 2000; Baier et al. 2010). In return, AM fungi store a portion of the photosynthetic products for their own growth (Godbold et al. 2006; Kiers et al. 2011). Four to twenty percent of plant photosynthetic products are transferred to the AM fungi to build hyphae that extend into the soil and influence soil C storage (Bago et al. 2000; Godbold et al. 2006). $A{ }^{13} \mathrm{C}$ labelling experiment has found that AMF received 4.3\% plant fixed $C$ in $24 \mathrm{~h}$ (Tomè et al. 2015). Kaiser et al. (2015) found that mycorrhizal fungi directly transported C from plant photosynthetic products to the soil and even to soil microbes (Kaiser et al. 2015). AM fungi therefore plays an important role in $C$ cycling from above- to below-ground.

Previous studies show that AM fungi affect the association between roots and soil by increasing nutrient uptake and the resistance of host plants to a range of environmental stresses and by promoting plant growth and development (Evelin et al. 2009; Hajiboland et al. 2010; Lee et al. 2012; Klein et al. 2016). A number of mechanisms are involved. Mycorrhizal inoculation can increase the chlorophyll content and the rate of photosynthesis and further increase plant $\mathrm{C}$ accumulation (Talaat and Shawky 2014). Plants inoculating with AM fungi show decreased $\mathrm{H}_{2} \mathrm{O}_{2}$ and increased malondialdehyde (MDA) contents compared to non-AM plants and increased soluble proteins and sugars, thereby increasing both resistance to environmental stress and the productivity of the host plants (Abdel Latef et al. 2016). Furthermore, inoculation facilitates the acquisition of mineral nutrients, especially P (Řezáčová et al. 2018). These studies indicate that $\mathrm{AM}$ fungal inoculation influences plant physiological traits and promotes $\mathrm{C}$ sequestration by host plants (Miller et al. 2002; Zhu and Miller 2003). In return, photosynthate is allocated belowground. An increase in root biomass may increase the space for colonization by AM fungi while AM inoculation decrease the root-to-shoot ratio through ameliorating plant nutrient status (Veresoglou et al. 2012). In addition, the AM fungi produce hyphae that extend into the soil and then exert important effects on the soil environment (Zhu and Miller 2003; Godbold et al. 2006). Hyphae, spores and vesicles of AM fungi are widely present in soils and the extraradical biomass can form up to $32 \%$ of the total soil microbial biomass, contributing up to $15 \%$ of SOC (Miller and Kling 2000). Some studies suggest an increased or accelerated photosynthetic down-regulation with AMF under greenhouse conditions (Goicoechea et al. 2014). Establishment of mycorrhizal symbiosis often increases allocation of $\mathrm{C}$ to the roots and further to the mycorrhizal fungi (Řezáčová et 
al. 2017). As feedback, the roots and AM fungi exude sugars and organic acids to the soil and thus to soil microorganisms, which may be activated to metabolize accumulated soil mineral nutrients for the growth of the host plants (Zhang et al. 2016). When hyphae die, a portion of their $\mathrm{C}$ is rapidly decomposed by other microorganisms and converted to $\mathrm{CO}_{2}$ which may enter the atmosphere or some recalcitrant organic compounds such as chitin and glomalin that can remain in the soil for years to decades (Gleixner et al. 2002; Wilson et al. 2009; Smith and Read 2010; Treseder 2013). In addition, the contribution of AM fungi to the $C$ cycle also depends on both the ERH and exudates from AM fungal hyphae such as glomalin which can contribute to soil $\mathrm{C}$ aggregation and soil quality enhancement (Wright and Upadhyaya 1996; Tisdall et al. 1997; Zhu and Miller 2003; Zhang et al. 2016). However, several research showed that plant $\mathrm{C}$ allocated to hyphae was high enough to cause the depression of host plants in some experiments especially in nutrient-limited areas or the establishment stages of roots and hyphae (Jakobsen 1999; Gavito et al. 2019).

It is important to promote vegetation restoration and soil organic matter accumulation for a mining area ecological restoration, understand the mechanisms by which AM fungi promote soil $\mathrm{C}$ storage is helpful. However, most studies have been conducted under field conditions and factors such as soil heterogeneity and climatic variability have had a substantial impact on the results. Recent efforts have been made to quantify how AM associations may affect the overall $C$ balance and $C$ fluxes in different types of photosynthetic metabolism using stable ${ }^{13} \mathrm{C}$ isotopes, but have ignored how much $\mathrm{C}$ the $\mathrm{AM}$ fungi receive because of the paucity of available methods to quantify this directly (Lendenmann et al. 2011; Slavíková et al. 2017; Řezáčová et al. 2017 and 2018).In previous studies, different results were got under different nutritional conditions, host plants and growth stages. Quantification of the contribution of AM fungi to the exchange of photosynthetic products between above- and below-ground pools have been based mainly on $\delta^{13} \mathrm{C}$ and $\mathrm{C} \%$ value, methods which cannot give a direct indication of the allocation of primary products. Here, a greenhouse experiment was conducted and ${ }^{13} \mathrm{CO}_{2}$ pulse labeling was used to quantify the effects of $\mathrm{AM}$ inoculation on the allocation of photosynthetic products above- and below-ground and the effects of AM fungal inoculation on $\mathrm{C}$ storage in plants and soil. The effects of hyphae on $\mathrm{C}$ allocation were studied using three-compartment microcosms to collect AM fungal biomass and then calculate the amount of ${ }^{13} \mathrm{C}$ in the biomass. The work aimed to unveil the mechanisms by which $\mathrm{AM}$ fungi promote $\mathrm{C}$ sinks in plants and soil under controlled conditions, and to provide a theoretical basis for the role of AM fungi in $\mathrm{C}$ storage in the soil and in photosynthate allocation above- and below-ground in a nutrient-poor soil from a coal mining area in northwest China.

\section{Materials And Methods Soil, plants and AM fungus}

Sandy soil collected from Daliuta mining area, Yulin, Shanxi Province, China was sieved $(\nabla 2 \mathrm{~mm})$, sterilized at $121^{\circ} \mathrm{C}$ and $103 \mathrm{kPa}$ for $2 \mathrm{~h}$ and air-dried for three days before use. Selected soil physicochemical properties were: available phosphorus (AP, $\mathrm{NaHCO}_{3}$ extracted), $2.97 \mathrm{mg} \mathrm{kg}^{-1}$; available potassium (AK), $12.9 \mathrm{mg} \mathrm{kg}^{-1}$; organic matter content, $1.25 \mathrm{~g} \mathrm{~kg}^{-1}$; $\mathrm{pH}, 7.39$; conductivity, $834 \mu \mathrm{S}$ $\mathrm{cm}^{-1}$; and water holding capacity, $18.6 \%$. The low AP, AK and conductivity indicate a nutrient-limited environment for plants. Maize (Zea mays L., cultivar Nuoyu 2) was selected as the host plant and seeds were provided by the Seeds Company of the Chinese Academy of Agricultural Sciences. They were surface sterilized by immersion in $10 \%(\mathrm{v} / \mathrm{v}) \mathrm{H}_{2} \mathrm{O}_{2}$ for 10 min, rinsed several times with distilled water and germinated at $25^{\circ} \mathrm{C}$ for $48 \mathrm{~h}$ in the dark. The AM fungal inoculum, Funneliformis mosseae, was provided by the Institute of Plant Nutrition and Resources, Beijing Academy of Agriculture and Forestry Sciences, Beijing, China and propagated at the State Key Laboratory for Coal Resources and Safe Mining, China University of Mining and Technology (Beijing). The inoculum consisted of spores (2000 spores per $100 \mathrm{~g}$ inoculum), external hyphae and mycorrhizal root fragments.

\section{Experimental design and management}

The experiment was conducted using $55 \times 28 \times 26 \mathrm{~cm}$ three-compartment microcosms (Fig. 1a). On the left was the root compartment $(\mathrm{RC})$, in the middle the buffer zone (BC) and on the right the hyphal compartment ( $\mathrm{HC})$. We used a 1-mm nylon mesh to allow hyphae and fine roots (but not coarse roots) into the $\mathrm{BC}$ in order to avoid the roots extending to the $\mathrm{HC}$ and ensuring enough hyphae in the $\mathrm{HC}$ for collection. The $\mathrm{BC}$ and $\mathrm{HC}$ were separated by $30-\mu \mathrm{m}$ pore nylon mesh to allow hyphae in and exclude all roots. The soil in the RC and $\mathrm{BC}$ was sterilized sandy soil sieved to $\nabla 2 \mathrm{~mm}$ and the medium in the $\mathrm{HC}$ was $0.8-1.2 \mathrm{~mm}$ glass beads immersed in $5 \% \mathrm{HCl}$ for $24 \mathrm{~h}$ and washed with distilled water several times before use to collect clean hyphae. There were $25 \mathrm{~kg}, 5 \mathrm{~kg}$ and $22 \mathrm{~kg}$ soil, respectively, in the $\mathrm{RC}, \mathrm{BC}$ and $\mathrm{HC}$ of each pot. Two treatments were established, mycorrhizal (inoculated with $F$. mosseae) and non-mycorrhizal controls (CK). One hundred of inoculum was applied to the root compartment of the mycorrhizal treatment by layering and the non- 
mycorrhizal treatment received $100 \mathrm{~g}$ sterilized inoculum. the effects of AM fungi on maize growth, stress resistance and $\mathrm{C}$ allocation were determined compared with the control. There were three replicates of each treatment and a total of six microcosms were used.

We added $100 \mathrm{mg} \mathrm{N}\left(\right.$ as $\mathrm{NH}_{4} \mathrm{NO}_{3}$ ), $30 \mathrm{mg} \mathrm{P}\left(\right.$ as $\mathrm{KH}_{2} \mathrm{PO}_{4}$ ), and $150 \mathrm{mg} \mathrm{K}\left(\mathrm{as} \mathrm{K}_{2} \mathrm{SO}_{4}\right.$ ) per $\mathrm{kg}$ to the $\mathrm{RC}$ to meet the basic nutrient demand of maize at the seedling stage, watered the soil to maximum water holding capacity and then preconditioned the soil for $24 \mathrm{~h}$ before transplanting. Maize seeds were sown in plastic seedling pots and then transplanted to the RC at the three-leaf stage on April 5th, 2017. There were two maize plants in each RC. An EM50 data logger (ICT International, Armidale, NSW, Australia) was used daily to maintain the soil moisture content within 75 to $80 \%$ of the water holding capacity. Deionized water $(100 \mathrm{ml})$ was added to the $\mathrm{HC}$ every day plus $100 \mathrm{ml} 1 / 10$ Hoagland's nutrient solution every three days to ensure hyphal growth. Maize growth was maintained by adding $50 \mathrm{mg} \mathrm{N}\left(\right.$ as $\left.\mathrm{NH}_{4} \mathrm{NO}_{3}\right), 15 \mathrm{mg} \mathrm{P}\left(\right.$ as $\left.\mathrm{KH}_{2} \mathrm{PO}_{4}\right)$, and $75 \mathrm{mg} \mathrm{K}\left(\right.$ as K$\left._{2} \mathrm{SO}_{4}\right)$ to the $\mathrm{RC}$ soil 25 days after transplanting to alleviate plant nutrient deficiency.

\section{${ }^{13} \mathrm{CO}_{2}$ pulse labeling chamber and procedure}

Previous studies indicate that ${ }^{13} \mathrm{C}$ from photosynthesis may be transferred to each plant part, AM fungi and soil and even to soil microbes within one day (Kuzyakov and Cheng 2004; Kaiser et al. 2015). ${ }^{13} \mathrm{CO}_{2}$ stable isotope pulse labeling for three days starting at the tasseling stage 63 days after transplanting was used to trace the distribution of maize photosynthetic $C$ among plant parts, AM fungus and soil. The labeling chamber was $110 \times 110 \times 75 \mathrm{~cm}$ in size (Fig. 1b). The mycorrhizal treatments and non-mycorrhizal controls were randomly placed in two labeling chambers with good light transmission and repositioned randomly each day to minimize variation due to the labeling process. LI-6400 handheld probes (LI-COR Biosciences, Lincoln, NE; to probe the real time concentration of $\mathrm{CO}_{2}$ ), air fans, silica gel and thermometers (to determine the real-time temperature) were placed in the airtight chambers before labeling as shown in Fig. $1 \mathrm{~b}$. The ${ }^{12} \mathrm{CO}_{2}$ in the labeling chamber was consumed by placing maize pots in the glasshouse chambers at 08:00 in the morning. When the $\mathrm{CO}_{2}$ concentration in the labeling chambers was $₫ 50 \mathrm{ppm}$ at $09: 00$ the ${ }^{13} \mathrm{CO}_{2}$ (atom $>99.99 \%$ ) gas was injected at 30-min intervals into the chambers to maintain a constant ${ }^{13} \mathrm{CO}_{2}$ concentration of $300-450 \mathrm{ppm}$. At $15: 00{ }^{13} \mathrm{CO}_{2}$ gas was injected for the last time and the concentration of ${ }^{13} \mathrm{CO}_{2}$ was $\leq 450 \mathrm{ppm}$. The labeling chambers were opened at 17:00 when labeling ended to ensure maize respiration during the night. The experiment was conducted in Beijing at China University of Mining and Technology $\left(40^{\circ} \mathrm{N}, 116^{\circ} \mathrm{E}\right)$. The weather was sunny and the temperatures on the three ${ }^{13} \mathrm{C}$-tracing days were, respectively, $40.7,37.5$, and $37.3^{\circ} \mathrm{C}$.

\section{Sampling and measurement}

The photosynthetic rates of the third and fourth fully expanded leaves (from the top) were measured at 10:00 one day before labeling to test the effects of the AM fungus on plant photosynthetic ability. An LI-6400 handheld probe (Licor Biosciences, Lincoln, NE) was used and the built-in red and blue light source, with a red light photosynthetic effective radiation flux density of $1000 \mu \mathrm{mol} \mathrm{m} \mathrm{m}^{-2} \mathrm{~s}^{-1}$ was used. The leaf chlorophyll content was measured with a SPAD-502 chlorophyll meter (Konica Minolta, Tokyo, Japan; Ling et al. 2011). Leaf starch and soluble sugar contents (fresh samples) were determined by anthrone colorimetry (Leach and Braun 2016) to determine plant stress resistance. Soluble protein was determined by the Coomassie brilliant blue G-250 staining method (Murphey et al. 1989) and malondialdehyde (MDA) content by the thiobarbituric acid (TBA) method (Schmedes and Hølmer 1989). Catalase (CAT) activity was determined by the potassium permanganate titration method (Chen et al. 2015). The plant and soil samples were collected after three days of labeling. The plants were divided into six parts to determine the allocation of carbon among plant parts, namely young leaves (leaves not fully expanded), intermediate leaves, senescent leaves (leaves with yellow edges and signs of senescence), dry leaves (completely withered leaves), stems, and roots. Leaf areas and shoot and root biomass were determined. All plant parts were oven-dried to constant weight and ground to $0.15 \mathrm{~mm}$. Shoot $\mathrm{P}$ and $\mathrm{K}$ concentrations were determined by digestion with $\mathrm{H}_{2} \mathrm{SO}_{4}-\mathrm{H}_{2} \mathrm{O}_{2}$ and analysis using ICP-AES (Thomas et al. 1967). Rhizosphere soil was sampled by the quartering method and then passed through a 2-mm sieve. The soil was divided into two portions to determine the carbon allocation to the soil and the effects of the AM fungus on soil properties. One portion was stored at $4^{\circ} \mathrm{C}$ to determine microbial biomass and the remainder was air-dried outdoors. Wet sieving was used to collect hyphae. The glass beads in the hyphal compartment were transferred to buckets and washed five times with distilled water. Glass rods were used to mixed the glass beads and water. The supernatant was immediately passed through a $30-\mu \mathrm{m}$ pore sieve to collect the hyphae. The AM fungal hyphae were dried at $80^{\circ} \mathrm{C}$, ground to $0.15 \mathrm{~mm}$ and homogenized before analysis. 
The carbon allocation, $\delta^{13} \mathrm{C}$ value and $\mathrm{C} \%$ content of each plant part and soil and hyphal samples were fully quantified using a Deltaplus XP mass spectrometer (Thermo Fisher, Waltham, MA) and an elemental analyzer at the stable isotope laboratory of the Chinese Academy of Agricultural Sciences. The accuracies of measurement of $C$ content and $C$ isotopic composition were $0.1 \%$ and $0.2 \%$, respectively (Deniro and Epstein 1978).

Root segments were stained with $0.05 \%$ Trypan blue and examined under a microscope (Nikon, Tokyo, Japan) to determine the percentage of root length colonized (Phillips and Hayman 1970). The mycorrhizal colonization in every compartment was calculated as the number of mycorrhizal root segments/total number of root segments examined $\times 100 \%$, which may be described as the percentage of root length colonized or the colonization frequency. The hyphal length density was determined by the method of Jakobsen et al. (1992). SOC content was determined by standard dichromate oxidation (Bremner and Jenkinson 1960). Briefly, the easily extractable soil glomalin (EEG) was extracted with alkaline citrate $(20 \mathrm{mM}, \mathrm{pH} 7)$ by autoclaving for $30 \mathrm{~min}\left(121^{\circ} \mathrm{C}\right)$ followed by centrifuging at $4000 \mathrm{rpm}$ for $5 \mathrm{~min}$ and collecting the supernatant. The supernatant was stained with Coomassie brilliant blue G-250 and detected by UV spectrophotometry. Total glomalin (TG) was extracted with alkaline citrate $(50 \mathrm{mM}, \mathrm{pH}$ 8) by autoclaving for 90 $\min \left(121^{\circ} \mathrm{C}\right)$ and centrifuging at $4000 \mathrm{rpm}$ for $5 \mathrm{~min}$. The cycle of extraction and centrifugation was repeated four times until the supernatant was almost transparent. The supernatants extracted each time were combined and estimated as TG (Wright and

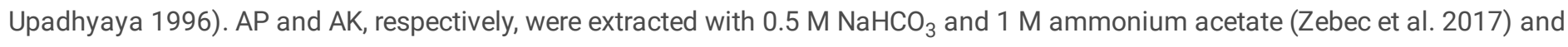
then determined by ICP-AES. Soil microbial biomass $C$ (MBC) and soil microbial biomass $N(M B N)$ were determined by chloroform fumigation and extraction with $0.5 \mathrm{M} \mathrm{K}_{2} \mathrm{SO}_{4}$ solution. $\mathrm{MBC}$ was determined using a total $\mathrm{C}$ analyzer and $\mathrm{MBN}$ using an automatic Kjeldahl nitrogen analyzer (Nguyen et al. 2016).

\section{Data calculations}

Total area of maize leaves (only green leaves) was calculated by the following equations.

$\mathrm{S}_{\mathrm{i}}=$ leaf length $\times$ maximum leaf width $\times 0.75(1 \mathrm{a})$

$$
S=\sum_{i}^{1} S i(1 b)
$$

where $\mathrm{Si}$ is area of a single leaf $\mathrm{i}$ and $\mathrm{S}$ is the total leaf area.

${ }^{13} \mathrm{C}$ distribution rate in each plant part:

$$
\delta^{13} C=\frac{R_{\text {samples }}-R_{P D B}}{R_{P D B}} \times 1000(2)
$$

$\mathrm{R},{ }^{13} \mathrm{C}$ concentration $/{ }^{12} \mathrm{C}$ concentration; PDB, Peedee belemnite in the Cretaceous Peedee formation, South Carolina, $\mathrm{R}_{\mathrm{PDB}}=(11237.2 \pm$ $90) \times 10^{-6}$.

$$
C \%=\frac{13 \times{ }^{13} C+12 \times{ }^{12} C}{M} \times 100(3)
$$

$\mathrm{M}$, dry weight of samples; ${ }^{13} \mathrm{C}$,the ${ }^{13} \mathrm{C}$ content in samples; ${ }^{12} \mathrm{C}$, the ${ }^{12} \mathrm{C}$ content in samples

$$
c\left({ }^{13} C\right)=\frac{13 \times \frac{C \%}{100}}{\frac{12 \times 1000}{\left(\delta^{13} C+1000\right) \times R_{P D B}}}(4)
$$

$c\left({ }^{13} \mathrm{C}\right)$, indicates the ${ }^{13} \mathrm{C}$ concentration in each plant and soil part

$$
m\left({ }^{13} C\right)=\frac{m \times \frac{C \%}{100}}{13+\frac{12 \times 1000}{\left(\delta^{13} C+1000\right) \times R_{P D B}}} \times 13
$$

$\mathrm{m}\left({ }^{13} \mathrm{C}\right),{ }^{13} \mathrm{C}$ content; indicates the ${ }^{13} \mathrm{C}$ weight in each plant and soil part 
The mycorrhizal contribution of each plant biomass and shoot $\mathrm{P}$ and $\mathrm{K}$ nutrition (MC\%):

$$
M C \%=\frac{\text { index }(\text { inoculated })-\text { index }(\mathrm{CK})}{\text { index }(\text { inoculated })} \times 100 \%
$$

\section{Data analysis}

All results in the Tables and Figures are mean value \pm standard error. The mean values of all data were compared to determine the difference between the inoculated treatment and uninoculated control. Student's t-test was used to determine the effects of inoculation at $P<0.05$ using the IBM SPSS 20.0 software package (IBM, Armonk, NY). The root mycorrhizal colonization data were normalized by arcsine-transformation before statistical analysis.

Differences between mycorrhizal treatment and non-mycorrhizal control of mycorrhizal colonization, hyphal length density, shoot and root biomass, $\mathrm{P}$ and $\mathrm{K}$ concentration, SPAD value, total leaf area, MDA, CAT, soluble protein, soluble sugar, and starch were compared by Student's t-test at $P<0.05$. The differences in photosynthetic indexes and soil physical and chemical properties between mycorrhizal and non-mycorrhizal treatments were compared by Student's t-test. Differences in $\delta^{13} \mathrm{C}, \mathrm{C} \%,{ }^{13} \mathrm{C}$ concentration and ${ }^{13} \mathrm{C}$ content in plants and soil samples between mycorrhizal and non-mycorrhizal treatments were also examined using Student's t-test.

\section{Results}

\section{Mycorrhizal colonization, hyphal length density and plant biomass and P and K concentrations}

As shown in Table 1 the roots in the inoculated treatment were colonized by $F$. mosseae in both the root and buffer compartments in which the root mycorrhizal colonization rate reached 77 and $81 \%$, respectively. The hyphal length density was $1.56 \mathrm{~m} \mathrm{~g}^{-1}$ soil in the root compartment with no colonization or mycelium found in the non-mycorrhizal control. Both mycorrhizal colonization and hyphal length density indicate that the AM fungus colonized the maize roots and the hyphae extended into the soil. Shoot, root and total biomass values were significantly higher in the mycorrhizal treatment than in the non-mycorrhizal control. The mycorrhizal contributions to shoot, root and total biomass were 13.6, 25.4 and 17.3\%, respectively. In addition, AM fungal inoculation significantly increased shoot $\mathrm{P}$ concentrations and contributed $45.4 \%$, which was $3.5 \mathrm{mg} \mathrm{g}^{-1}$ in mycorrhizal treatment but only $1.9 \mathrm{mg} \mathrm{g}^{-1}$ in nonmycorrhizal treatment. There was no influence observed on $\mathrm{K}$ concentrations (Table 1).

Table 1

Mycorrhizal colonization, hyphal length density, maize biomass and mycorrhizal contribution. Values are mean values \pm standard errors. Different lowercase letters represent significant differences between Myc (inoculated treatment) and Ctrl (uninoculated control) at $P<0.05$. RC, root compartment; BC, buffer compartment; and MC\%, mycorrhizal contribution.

\begin{tabular}{|c|c|c|c|c|c|c|c|c|}
\hline \multirow[t]{2}{*}{ Treatment } & \multicolumn{2}{|c|}{$\begin{array}{l}\text { Mycorrhizal colonization } \\
(\%)\end{array}$} & \multirow{2}{*}{$\begin{array}{l}\text { Hyphal } \\
\begin{array}{l}\text { length } \\
\text { density }\end{array} \\
\left(\mathrm{m} \mathrm{g}^{-1}\right)\end{array}$} & \multirow{2}{*}{$\begin{array}{l}\text { Shoot } \\
\text { biomass } \\
\left.\text { (g plant }^{-1}\right)\end{array}$} & \multirow{2}{*}{$\begin{array}{l}\text { Root } \\
\text { biomass } \\
\left.\text { (g plant }^{-1}\right)\end{array}$} & \multirow{2}{*}{$\begin{array}{l}\begin{array}{l}\text { Total } \\
\text { biomass }\end{array} \\
\left.\text { (g plant }^{-1}\right)\end{array}$} & \multirow[t]{2}{*}{$\begin{array}{l}\text { Shoot } P \\
\text { concentration } \\
\left(\mathrm{mg} \mathrm{g}^{-1}\right)\end{array}$} & \multirow[t]{2}{*}{$\begin{array}{l}\text { Shoot K } \\
\text { concentration } \\
\left(\mathrm{mg} \mathrm{g}^{-1}\right)\end{array}$} \\
\hline & $\mathrm{RC}$ & $\mathrm{BC}$ & & & & & & \\
\hline $\begin{array}{l}\operatorname{Myc}(F \\
\text { mosseae })\end{array}$ & $76.67 \pm 3.33$ & $81.11 \pm 3.85$ & $1.56 \pm 0.05$ & $20.5 \pm 0.77^{a}$ & $9.46 \pm 0.28^{a}$ & $30.0 \pm 0.85^{\mathrm{a}}$ & $3.50 \pm 0.32^{\mathrm{a}}$ & $80.7 \pm 9.43$ \\
\hline Control & None & None & None & $17.7 \pm 0.48^{\mathrm{a}}$ & $7.06 \pm 0.32^{b}$ & $24.8 \pm 0.45^{b}$ & $1.91 \pm 0.34^{\mathrm{b}}$ & $73.3 \pm 8.34$ \\
\hline $\mathrm{MC} \%$ & None & None & None & 13.6 & 25.4 & 17.3 & 45.4 & 9.15 \\
\hline
\end{tabular}

\section{Physiological characteristics and photosynthetic indices of maize}

Inoculation with F. mosseae increased plant resistance to environmental stress and the photosynthetic efficiency. As shown in Table 2, inoculation significantly increased CAT activity and the soluble protein, soluble sugar and starch contents of leaves $(P<0.05)$, by $2 \mathrm{U}$ $\mathrm{g}^{-1} \mathrm{FW} \mathrm{min}-1,0.02 \mathrm{mg} \mathrm{g}^{-1}, 0.5 \%$ and $0.11 \%$, respectively. MDA, which can indicate plant senescence, also decreased significantly in 
the mycorrhizal treatment. In addition, inoculation significantly promoted plant photosynthetic ability. Furthermore, the Pn significantly increased from 31.0 to $33.5 \mu \mathrm{mol} \mathrm{CO} \mathrm{m}^{-2} \mathrm{~s}^{-1}$ because of AM fungal inoculation (Table 3). Inoculation also increased plant resistance to high temperatures by increasing the $\mathrm{Tr}$ and decreasing leaf temperature (Table 3). Inoculation decreased the $\mathrm{Ci}$ owing to decreased respiration and increased photosynthesis. Thus, inoculation promoted both resistance of maize to stress and photosynthetic $\mathrm{C}$ fixation.

Table 2

Physiological characteristics of maize in the mycorrhizal and non-mycorrhizal treatments. Values are the mean values \pm standard errors. Different lowercase letters represent significant differences between Myc (inoculated treatment) and Ctrl (uninoculated control) at $P<0.05$. SPAD, leaf chlorophyll content; MDA, malondialdehyde content; CAT, catalase activity. Pn: net photosynthetic rate; Gs: stomatal conductance; $\mathrm{Ci}$ : intercellular $\mathrm{CO}_{2}$ concentration; $\mathrm{Tr}$ : transpiration rate; $\mathrm{T}$ : leaf temperature.

\begin{tabular}{|llllllll|}
\hline Treatment & SPAD & $\begin{array}{l}\text { Total leaf } \\
\text { area }\left(\mathbf{m}^{2}\right)\end{array}$ & $\begin{array}{l}\text { MDA }(\mu \mathrm{mol} \\
\left.\mathbf{g}^{-1}\right)\end{array}$ & $\begin{array}{l}\mathrm{CAT}\left(\mathrm{u} \mathrm{g} \mathrm{g}^{-1} \mathrm{FW}\right. \\
\left.\mathrm{min}^{-1}\right)\end{array}$ & $\begin{array}{l}\text { soluble protein } \\
\left(\mathrm{mg} \mathrm{g}^{-1}\right)\end{array}$ & $\begin{array}{l}\text { soluble } \\
\text { sugar }(\%)\end{array}$ & Starch (\%) \\
\hline Mycorrhizal & $38.2 \pm 0.56^{\mathrm{a}}$ & $0.15 \pm 0.01^{\mathrm{a}}$ & $6.16 \pm 1.31^{\mathrm{b}}$ & $4.93 \pm 0.64^{\mathrm{a}}$ & $0.22 \pm 0.01^{\mathrm{a}}$ & $1.02 \pm 0.09^{\mathrm{a}}$ & $0.58 \pm 0.02^{\mathrm{a}}$ \\
\hline Control & $33.7 \pm 1.00^{\mathrm{b}}$ & $0.13 \pm 0.00^{\mathrm{b}}$ & $15.7 \pm 0.10^{\mathrm{a}}$ & $2.95 \pm 0.21^{\mathrm{b}}$ & $0.20 \pm 0.00^{\mathrm{b}}$ & $0.70 \pm 0.00^{\mathrm{b}}$ & $0.47 \pm 0.02^{\mathrm{b}}$ \\
\hline
\end{tabular}

Table 3

Photosynthetic indices of maize. Values are mean values \pm standard errors. Different lowercase letters represent significant differences between Myc (inoculated treatment) and $\mathrm{Ctrl}$ (uninoculated control) at $P<0.05$. Pn, net photosynthetic rate; Gs, stomatal conductance; $\mathrm{Ci}$, intercellular $\mathrm{CO}_{2}$ concentration; $\mathrm{Tr}$, transpiration rate; $\mathrm{T}$, leaf temperature.

\begin{tabular}{|llllll|}
\hline Treatment & $\begin{array}{l}\mathrm{Pn}\left(\mu \mathrm{mol} \mathrm{CO} \mathrm{m}^{-2}\right. \\
\left.\mathbf{s}^{-1}\right)\end{array}$ & $\begin{array}{l}\mathrm{Gs}\left(\mathrm{mmol} \mathrm{H}_{2} \mathrm{O} \mathrm{m}^{-2}\right. \\
\left.\mathbf{s}^{-1}\right)\end{array}$ & $\begin{array}{l}\mathrm{Ci}(\mu \mathrm{mol} \mathrm{CO} \\
\left.\mathbf{s}^{-1}\right)\end{array}$ & $\begin{array}{l}\mathrm{Tr}\left(\mathrm{mmol} \mathrm{H}_{2} \mathrm{O} \mathrm{m}^{-2}\right. \\
\left.\mathbf{s}^{-1}\right)\end{array}$ & $\mathrm{T}\left({ }^{\circ} \mathrm{C}\right)$ \\
\hline Mycorrhizal & $33.5 \pm 0.58^{\mathrm{a}}$ & $0.042 \pm 0.00^{\mathrm{a}}$ & $84.8 \pm 9.07^{\mathrm{a}}$ & $4.39 \pm 0.11^{\mathrm{a}}$ & $32.7 \pm 0.18^{\mathrm{b}}$ \\
\hline Control & $31.0 \pm 1.44^{\mathrm{b}}$ & $0.046 \pm 0.00^{\mathrm{a}}$ & $91.2 \pm 1.89^{\mathrm{a}}$ & $4.14 \pm 0.10^{\mathrm{b}}$ & $33.27 \pm 0.20^{\mathrm{a}}$ \\
\hline
\end{tabular}

\section{${ }^{13} \mathrm{C}$ assimilation and allocation}

AM fungal inoculation significantly influenced the $\delta^{13} \mathrm{C}, \mathrm{C} \%,{ }^{13} \mathrm{C}$ concentration and ${ }^{13} \mathrm{C}$ content of intermediate leaves, roots, soil and hyphae at $P<0.05$ and significantly increased the $\mathrm{C} \%$ of the soil (Fig. 2). The ${ }^{13} \mathrm{C}$ concentration and content of maize and soil were significantly higher in the mycorrhizal treatment than in the non-mycorrhizal control, indicating that the AM fungus promoted $\mathrm{C}$ fixation in both maize and soil. The ${ }^{13} \mathrm{C}$ concentration of maize followed the sequence: young leaves > stems > intermediate leaves > senescent leaves $>$ roots. The ${ }^{13} \mathrm{C}$ concentration in the hyphae of the $\mathrm{AM}$ fungus was about $100 \mu \mathrm{g} \mathrm{g}^{-1}$, equivalent to that in the intermediate and senescent leaves of maize and much higher than in the roots (Fig. 2C). The sum of ${ }^{13} \mathrm{C}$ fixation in above- and below-ground parts in the mycorrhizal treatment was $4.00 \mathrm{mg}$ while it was $3.02 \mathrm{mg}$ on the non-mycorrhizal control (Fig. $2 \mathrm{~d}$ ). The MC\% to the sum of ${ }^{13} \mathrm{C}$ content in all parts was $25 \%$ and was $24 \%$ to ${ }^{13} \mathrm{C}$ content only in soil (Fig. $2 \mathrm{~d}$ ). Although the ${ }^{13} \mathrm{C}$ content in maize shoots increased, the percentage of the ${ }^{13} \mathrm{C}$ in maize shoots declined by $5.89 \%$, possibly indicating that inoculation promoted $\mathrm{C}$ accumulation and allocation to the belowground parts. Compared to the non-mycorrhizal control, mycorrhizal inoculation reduced the proportion of the ${ }^{13} \mathrm{C}$ distribution to the stems but increased the percentages of the distribution to the roots, soil and hyphae (Fig. 3). The ${ }^{13} \mathrm{C}$ content belowground involved soil, hyphae and roots, accounting for about $17.7 \%$ of the total ${ }^{13} \mathrm{C}$ content and much higher than the $11.8 \%$ in the non-mycorrhizal control (Fig. 2d). As a result, the AM fungus increased photosynthetic $\mathrm{C}$ fixation and soil $\mathrm{C}$ content. Inoculation also changed the distribution of photosynthetic products among shoots, roots and soil and tended to promote the allocation of photosynthetic $\mathrm{C}$ belowground.

\section{Soil properties}

As shown in Table 4 the SOC, EEG and TG values in the inoculated treatment were, respectively, $0.64,173$ and $515 \mathrm{~g} \mathrm{~kg}^{-1}$ and increased by $21.2,85.9$ and $62.4 \%$ compared to the non-mycorrhizal control. Inoculation also promoted the biomass of soil microorganisms. The MBC and MBN in the mycorrhizal treatment were 100 and $46.7 \mathrm{mg} \mathrm{kg}^{-1}$ and were significantly higher than in the non-mycorrhizal control. Soil AP in the mycorrhizal treatment was significantly lower than in the control but there was no significant difference in soil AK between mycorrhizal and non-mycorrhizal treatments. This may be related to the higher shoot biomass and larger microbial 
biomass in the mycorrhizal treatment. Here, mycorrhizal inoculation increased soil C deposition and the biomass of soil microorganisms while reducing soil available $\mathrm{P}$ and $\mathrm{K}$ contents.

Table 4

Effect of mycorrhizal inoculation on soil parameters. Values are mean values \pm standard errors. Different lowercase letters represent significant differences between Myc (inoculated treatment) and Ctrl (uninoculated control) at $P<0.05$. AK, available potassium; AP, available phosphorus; SOC, soil organic carbon; TG, total glomalin; EEG. easily extractable glomalin; MBC, soil microbial biomass carbon; MBN, soil microbial biomass nitrogen.

\begin{tabular}{|c|c|c|c|c|c|c|c|}
\hline Treatment & $\begin{array}{l}\text { AK (mg } \\
\left.\mathrm{kg}^{-1}\right)\end{array}$ & $\begin{array}{l}\mathrm{AP}(\mathrm{mg} \\
\left.\mathrm{kg}^{-1}\right)\end{array}$ & $\begin{array}{l}\mathrm{SOC}(\mathrm{g} \\
\left.\mathrm{kg}^{-1}\right)\end{array}$ & $\begin{array}{l}\mathrm{TG}(\mathrm{mg} \\
\left.\mathrm{kg}^{-1}\right)\end{array}$ & $\begin{array}{l}\text { EEG (mg } \\
\left.\mathrm{kg}^{-1}\right)\end{array}$ & $\begin{array}{l}\mathrm{MBC} \text { (mg } \\
\left.\mathrm{kg}^{-1}\right)\end{array}$ & $\begin{array}{l}\text { MBN (mg } \\
\left.\mathrm{kg}^{-1}\right)\end{array}$ \\
\hline Mycorrhizal & $148 \pm 18.37^{a}$ & $9.05 \pm 0.87^{b}$ & $0.64 \pm 0.03^{a}$ & $515 \pm 50.05^{a}$ & $137 \pm 32.65^{a}$ & $100 \pm 11.65^{a}$ & $46.7 \pm 3.21^{a}$ \\
\hline Control & $166 \pm 14.77^{a}$ & $13.3 \pm 0.48^{a}$ & $0.53 \pm 0.04^{b}$ & $317 \pm 52.24^{b}$ & $73.9 \pm 16.69^{b}$ & $62.4 \pm 6.89^{b}$ & $27.2 \pm 3.94^{b}$ \\
\hline
\end{tabular}

\section{Discussion}

\section{Validation of a novel method for fully quantifying carbon allocation in the plant-AM fungus-soil system}

The contribution of AM fungi to $\mathrm{C}$ allocation and sequestration belowground has long been a matter of interest and debate because accurate quantification, especially in realistic conditions, is very difficult (Parihar et al. 2020). There are a number of approaches to the estimation of the amount of $\mathrm{C}$ allocated to mycorrhiza. Numerous recent efforts have been made to quantify how AM symbiosis would affect the overall $\mathrm{C}$ balance and $\mathrm{C}$ fluxes in different type of photosynthetic metabolism using the stable ${ }^{13} \mathrm{C}$ isotope (Lendenmann et al. 2011; Slavíková et al. 2017; Řezáčová et al. 2017 and 2018). The amounts of plant and soil carbon have been calculated and it has been reported that AM fungi increased assimilation by plants and the carbon allocation to soil. However, how much carbon AM fungi receive is unclear because it is difficult to collect hyphae from soil. In addition, NanoSIMS has demonstrated that AM fungi transferred $\mathrm{C}$ to soil and soil microbes (Kaiser et al. 2015). However, it is difficult to calculate the absolute amount of carbon. Here, we used a compartment culture system and mixed glass beads with soil to collect AM fungal hyphae, and combined with hyphal weight, the carbon allocation to the AM fungus was calculated. In addition, separated plant parts were studied in order to understand the carbon allocation in more details. Numerous studies report that aboveground respiration levels in mycorrhizal treatments declined coincident with increased C drain belowground (Řezáčová et al. 2017 and 2018). Here, we focus on the carbon assimilated to organic matter. Although a large percentage of carbon assimilated by photosynthesis is used for respiration, it is related to the carbon in organic matter (Smith and Dukes 2003).

\section{The AM fungus increased plant growth and $\mathrm{C}$ allocation by enhancing the potential of plant stress resistance and nutrient uptake}

Numerous previous studies have shown plant growth responses to mycorrhizal inoculation including positive (mutualism), neutral (commensalism) and negative (parasitism) effects (Johnson et al. 1997; Klironomos 2003). AM fungi form potentially symbiotic relationships with host plants based on the exchange of nutrients, especially relatively immobile nutrients such as $\mathrm{P}$, and plant primary products (Kiers et al. 2011). According to the assumption of the bio-market model the effect of AM fungi on the growth of host plants lies in the trade-off between the $C$ cost to and the nutrient acquisition by the host plants (Kiers et al. 2011). Here, the AM fungus formed large amounts of hyphae and increased the biomass, leaf area and P level of maize while decreasing soil available P and K (Tables 1 , 2 and 4). These results indicate that the mycorrhizal benefits of nutrient uptake exceeded the $\mathrm{C}$ cost to the plant to construct the hyphal network. Especially, the shoot P concentration in mycorrhizal treatment was much higher than it in non-mycorrhizal treatment which was lower than threshold of shoot P concentration from silking stage to mature stage of maize (Jones 1983).Inoculation with the AM fungus also significantly increased leaf chlorophyll content and plant net photosynthetic rate resulting in the accumulation of primary products such as starch, while the intercellular $\mathrm{CO}_{2}$ concentration decreased in the mycorrhizal treatment and this is consistent with previous studies (Borde et al. 2010; Talaat and Shawky 2014). In addition, soluble sugars and soluble proteins increased as a result of mycorrhiza-mediated enhanced photosynthesis (Table 2). When soluble sugars and soluble proteins increase the resistance to stress of the host plants is enhanced (Latef and Huang 2011; Sheng et al. 2011). Furthermore, the MDA content in the leaves decreased significantly while CAT in the leaves increased in the mycorrhizal treatment (Table 2). Lower $\mathrm{H}_{2} \mathrm{O}_{2}$ and MDA contents compared to nonmycorrhizal controls reduce oxidative (or other) stresses (Latef and Huang 2011; Talaat and Shawky 2014; Yang et al. 2014). Here, mycorrhizal inoculation reduced the temperature of leaf surfaces and increased the ability of the plants to resist high temperatures that might occur in northern Chinese coal mining areas (Table 3), perhaps by increasing the transpiration rate (Lee et al. 2012) Above all,

Page $8 / 18$ 
AM fungi may increase the potential resistance to environmental stress in coal mining areas and increase their nutrient uptake capacity, as well as contributing to plant growth and the accumulation of photosynthetic products (Xie et al. 1995; Hajiboland et al. 2010).

\section{AM fungi regulate the allocation of photosynthetic products}

Symbiotic associations between AM fungi and plants affect the transportation and allocation of photosynthetic products in plants (Lendenmann et al. 2011; Slavíková et al. 2017; Řezáčová et al. 2018). Here, the ${ }^{13} \mathrm{CO}_{2}$ pulse labeling method was used to label the maize and quantitatively determine the allocation of photosynthetic $C$ in various plant parts and in the soil and the inoculated $A M$ fungus and this is consistent with previous studies. Inoculation with the AM fungus increased the concentration and total amount of ${ }^{13} \mathrm{C}$ in the plants (Fig 2 and 3 ). This is supported by previous studies showing that AM fungi increase the $\mathrm{C}$ fixation capacity of their host plants (Hoeksema et al. 2010). We also observed significantly higher ${ }^{13} \mathrm{C}$ concentrations in the intermediate leaves and roots in the mycorrhizal treatment as well as higher concentrations of ${ }^{13} \mathrm{C}$ in the young and senescent leaves and stems than in nonmycorrhizal controls (Fig 2c). Higher ${ }^{13} \mathrm{C}$ concentrations in plant parts indicate stronger photosynthesis in young leaves than the intermediate and senescent leaves. Here, inoculation with the AM fungus increased the ${ }^{13} \mathrm{C}$ content in the plants and soil and also significantly changed the allocation of ${ }^{13} \mathrm{C}$ between the above- and below-ground parts of the system (Fig 3). Although inoculation increased the concentration of total ${ }^{13} \mathrm{C}$ and each part of the ${ }^{13} \mathrm{C}$, the above-ground ${ }^{13} \mathrm{C}$ allocation ratio in the inoculated treatment decreased by $5.89 \%$. This indicates that inoculation promoted photosynthesis and altered plant physiology while promoting the transportation of photosynthetic products belowground. This is supported by studies in which associations between AM fungi and host plants have accelerated the transport of photosynthetic products from leaves to roots and through stems. Furthermore, promotion of photosynthesis helps plant photosynthetic C fixation (Jakobsen and Rosendahl 1990; Al-Karaki 2000; Drigo et al. 2010; Olsson et al. 2010). Here, the $\mathrm{C} \%$ and ${ }^{13} \mathrm{C}$ concentrations in the hyphae were equivalent to those in the leaves and were higher than in the roots (Fig $2 \mathrm{~b}$ and $2 \mathrm{c}$ ). This is consistent with a previous study in which ${ }^{14} \mathrm{C}$ was fixed by plants and then transferred to AM fungi within a few minutes (Clemmensen et al. 2013). In fact, AM fungi contain 5 to $20 \%$ of the photosynthetic C (Jakobsen and Rosendahl 1990; Johnson et al. 1997). Therefore, AM fungi are regulators of C flux pools from above- to below-ground (Zhu and Miller 2003).

\section{AM fungi enhance $C$ flux to soil microorganisms}

Mycorrhizal inoculation significantly increased SOC and glomalin in the soil (Table 4). When a symbiotic relationship has formed a portion of the photosynthetic products is allocated to the AM fungi for extension of hyphae and development of spores in the soil (Gavito et al. 2005; Godbold et al. 2006). Previous studies show that the turnover time is usually 5-6 days. When the AM fungi die, part of their $\mathrm{C}$ may be decomposed by other microorganisms and then released to the atmosphere or enter the soil $\mathrm{C}$ cycle (Staddon et al. 2003; Treseder 2013). There is also a portion of $C$ produced by AM fungi, for example in their cell walls, in the form of chitin that can remain in the soil for decades. The soil average organic $C$ content in the inoculated treatment increased by $21.3 \%$ compared with the uninoculated control (Table 4). Thus, although the AM fungus had a rapid turnover rate in the soil the $\mathrm{C}$ stored by the fungus in the soil was measurable, maintaining a stable hyphal network that is important in soil C sequestration (Friese and Allen 1991). In the mycorrhizal treatment the soil contents of EEG and TG increased significantly (Table 4), indicating that the content of soil glomalin was closely related to the AM fungus (Wright and Upadhyaya 1996). Studies show that AM fungi can produce exudates such as glomalin that are stable in the soil and influence the soil C storage indirectly by stabilizing soil aggregates (Steinberg and Rillig 2003; Rillig and Mummey 2006). This indicates that soil $\mathrm{C}$ deposition is not only affected by the $\mathrm{C}$ turnover in the mycelium but also by the protection of exudates of AM fungi and hyphal networks (Miller and Jastrow 2000; Zhu and Miller 2003).

\section{AM fungi regulate above-belowground feedback}

It is reported that soil organisms are important drivers of plant growth and then the effect of plants on soil community may influence the plants that grow later in the soil (Van der Putten et al. 2013; Wilschut et al. 2019). Once a symbiotic relationship is established it can extend the range of uptake by plant roots from a few millimeters to 12 centimeters, increasing the efficiency of soil nutrient utilization (Li et al. 1991). Therefore, in the mycorrhizal treatment the contents of available $\mathrm{P}$ in the soil declined significantly (Table 4). The results support the prevalence of a positive plant-soil feedback in the AM system (Bahram et al. 2020). Interaction between the host plants and the AM fungus increased the nutritional status of the host plants and also promoted plant growth and nutrient especially P status and the distribution of photosynthetic products belowground to supply both the roots and the AM fungus (Table 1). The results support the promotion of the accumulation of $\mathrm{C}$ in the soil by the AM fungal association by promoting the distribution of 
photosynthetic products from the above-ground parts of the host plant to the intra- and extraradical mycelium (Leake et al. 2004). This stimulates the accumulation of microbial biomass. The hyphae release exudates and stabilize the soil structure and can also provide $\mathrm{C}$ sources for the soil microbial community and promote the growth of soil microorganisms (Toljander et al. 2007; Jones et al. 2009). Soil microorganisms are the most active part of the soil. They play an important role in soil nutrient acquisition and organic matter mineralization to meet the growth needs of plants and AM fungi (Hodge et al. 2001; Scheublin et al. 2010; Jansa et al. 2013; Wang et al. 2016; Zhang et al. 2018). Therefore, a mutually beneficial system is formed among host plants, AM fungi and soil microorganisms which affects the soil $\mathrm{C}$ cycle and enhances soil nutrient conditions. Here, AM inoculation promoted the growth and $\mathrm{P}$ nutrition of maize in the nutrient-limited soil and the photosynthetic $\mathrm{C}$ allocation to the soil. The enhanced microbial and environmental conditions in the nutrient-poor soil regulated a good feedback mechanism to increase plant growth.

\section{Conclusions}

Here, we established a suitable method to quantify the carbon allocation in plants, AM fungus and soil, and additionally in different plant parts. We also determined soil nutrient and SOC change caused by the AM fungus to detect above-belowground feedback regulated by the AM fungal association. Our results indicate that mycorrhizal colonization aided in the promotion of plant growth through increased stress resistance and mineral nutrient uptake. The AM fungus regulated the carbon allocation to functional leaves and increased plant photosynthetic activity. Mycorrhizal colonization also stimulated $\mathrm{C}$ allocation belowground to roots, hyphae and microorganisms. Soil available P and K contents decreased significantly because of the mycorrhizal nutrient uptake pathway to host plants. The positive feedback regulated by the AM fungus was established (Fig. 4). Mycorrhizal inoculation may therefore be a useful technique for ecological restoration and land reclamation in mining areas of northwest China, acting through above-belowground interactions and positive feedback. However, the current pot experiment was conducted in greenhouse conditions and further studies are required to verify the results under field conditions.

\section{Declarations}

\section{Acknowledgements}

Not acceptable.

\section{Ethical Approval}

Not applicable

\section{Consent to Participate}

Not applicable

\section{Consent to Publish}

Not applicable

\section{Funding}

This study was funded by the by the National Natural Science Foundation of China (51974326) and the Capital Science and Technology Leading Talent Project (Z18110006318021).

\section{Authors' contributions}

YL Bi, $P$ Christie, Y Cai and X Wang designed the study. Y Cai performed the plant culture and chemical analysis. YL Bi, P Christie and X Wang contributed to statistical interpretation of results and wrote the manuscript. All authors read and approved the final manuscript.

\section{Conflict of Interest Statement}

The authors declare that they have no conflict of interest.

\section{Availability of data and materials}


The datasets generated during and/or analysed during the current study are available from the corresponding author on reasonable request.

\section{References}

1. Al-Karaki GN (2000) Growth of mycorrhizal tomato and mineral acquisition under salt stress. Mycorrhiza 10:51-54. https://doi.org/10.1007/s005720000055

2. Andrade G, Mihara KL, Linderman RG, Bethlenfalvay GJ (1998) Soil aggregation status and rhizobacteria in the mycorrhizosphere. Plant Soil 202:89-96. https://doi. org/10.1023/A:1004301423150

3. Bago B, Pfeffer PE, Shachar-Hill Y (2000) Carbon metabolism and transport in arbuscular mycorrhizas. Plant Physiol 124:949958. https://doi.org/10.1104/pp.124.3.949

4. Bahram M, Netherway T, Hildebrand F, Pritsch K, Drenkhan R, Loit K, Anslan S, Bork P, Tedersoo L (2020) Plant nutrient-acquisition strategies drive topsoil microbiome structure and function. New Phytol 227:1189-1199. https://doi.org/10.1111/nph.16598

5. Baier MC, Keck M, Go $d$ dde V, Niehaus K, Ku匹ster H, Hohnjec N (2010) Knockdown of the symbiotic sucrose synthase MtSucS1 affects arbuscule maturation and maintenance in mycorrhizal roots of Medicago truncatula. Plant Physiol 152(2): 10001014. https://doi.org/10.1104/pp.109.149898

6. Beltrano J, Ruscitti M, Arango MC, Ronco M (2013) Effects of arbuscular mycorrhiza inoculation on plant growth, biological and physiological parameters and mineral nutrition in pepper grown under different salinity and P levels. J Plant Nutri Soil Sci 13:123141. http://dx.doi.org/10.4067/S0718-95162013005000012

7. Bethlenfalvay GJ, Brown MS, Ames RN, Thomas RS (1988) Effects of drought on host and endophyte development in mycorrhizal soybeans in relation to water use and phosphate uptake. Physiol Plant 72(3):565-571. https://doi.org/10.1111/j.13993054.1988.tb09166.x

8. Bi Y, Wang K, Wang J (2018) Effect of different inoculation treatments on AM fungal communities and the sustainability of soil remediation in Daliuta coal mining subsidence area in northwest China. App Soil Ecol 132:107-113. http://d oi.org/10.1016/j.apsoil.2018.08.009

9. Bi Y, Zhang J, Song Z, Wang Z, Qiu L, Hu J, Gong Y (2019) Arbuscular mycorrhizal fungi alleviate root damage stress induced by simulated coal mining subsidence ground fissures. Sci Total Environ 652:398-405. https://doi.org/10.1016/ j.scitotenv.2018.10.249

10. Black KG, Mitchell DT, Osborne BA (2000) Effect of mycorrhizal-enhanced leaf phosphate status on carbon partitioning, translocation and photosynthesis in cucumber. Plant Cell Environ 23(8):797-809. https://doi.org/10.1046/j.13653040.2000.00598.x

11. Borde M, Dudhane M, Jite PK (2010) AM fungi influences the photosynthetic activity, growth and antioxidant enzymes in Allium sativum L. under salinity condition. Notulae Scientia Biologicae 2:64-71. https://doi.org/10.15835/nsb245434

12. Bremner JM, Jenkinson DS (1960) Determination of organic carbon in soil: I. Oxidation by dichromate of organic matter in soil and plant materials. J Soil Sci 11:394-402. https://doi.org/10.1111/j.1365-2389.1960.tb01093.x

13. Chen Q, Cheng M, Wang Y, Yao M, Chen YC, Gao Y, Ding WY (2015) A simple method of catalase purification for the undergraduate experimental course. Mol Med Rep 11:1340-1343. https://doi.org/10.3892/mmr.2014.2806

14. Clemmensen KE, Bahr A, Ovaskainen O, Dahlberg A, Ekblad A, Wallander H, Stenlid J, Finlay RD, Wardle DA, Lindahl BD (2013) Roots and associated fungi drive long-term carbon sequestration in boreal forest. Science 339:1615-1618. https:// doi.org/10.1126/science.1231923

15. De S, Mitra AK (2002) Reclamation of mining-generated wastelands at Alkusha-Gopalpur abandoned open cast project, Raniganj coalfield, eastern India. Env Geol 43:39-47. https://doi.org/10.1007/s00254-002-0635-7

16. DeNiro MJ, Epstein S (1978) Carbon isotopic evidence for different feeding patterns in two hyrax species occupying the same habitat. Science 201:906-908. https:// doi.org/10.1126/science.201.4359.906

17. Dijkstra FA, Cheng W (2007) Interactions between soil and tree roots accelerate long-term soil carbon decomposition. Ecol Lett 10:1046-1053. 0248.2007.01095.x

18. Drigo B, Pijl AS, Duyts H, Kielak AM, Gamper HA, Houtekamer MJ, Boschker HTS, Bodelier PLE, Whiteley AS, van Veen JA, Kowalchuk GA (2010) Shifting carbon flow from roots into associated microbial communities in response to elevated atmospheric 
$\mathrm{CO}_{2}$. Proc Nat Acad Sci USA 107:10938-10942. https://doi.org/10.1073/pnas.0912421107

19. Evelin H, Kapoor R, Giri B (2009) Arbuscular mycorrhizal fungi in alleviation of salt stress: a review. Ann Bot 104:1263-1280. https://doi.org/10.1093/aob/mcp251

20. Friese CF, Allen MF (1991) Tracking the fates of exotic and local VA mycorrhizal fungi: methods and patterns. Agric. Ecosyst Environ 34:87-96. https://doi.org/10.1016/0167-8809(91)90096-G

21. Gavito ME, Jakobsen I, Mikkelsen TN, Mora F (2019) Direct evidence for modulation of photosynthesis by an arbuscular mycorrhiza-induced carbon sink strength. New Phytol 223:896-907. https://doi.org/10.1111/nph.15806Gavito Olsson ME, Rouhier PA, H, Medina-Peñafiel A, Jakobsen, Bago I, Azcón-Aguilar A C

22. Temperature constraints on the growth and functioning of root organ cultures with arbuscular mycorrhizal fungi. New Phytol 168:179-188. https://doi.org/10.1111/j.1469-8137.2005.01481.x

23. Gleixner G, Poirier N, Bol R, Balesdent J (2002) Molecular dynamics of organic matter in a cultivated soil. Org Geochem 33:357366. https://doi.org/10.1016/S0146-6380(01)00166-8

24. Godbold DL, Hoosbeek MR, Lukac M, Cotrufo MF, Janssens IA, Ceulemans R, Polle A, Velthorst EJ, Scarascia-Mugnozza G, De Angelis P, Miglietta F, Peressotti A (2006) Mycorrhizal hyphal turnover as a dominant process for carbon input into soil organic matter. Plant Soil 281:15-24. https://doi.org/10.1007/s11104-005-3701-6

25. Goicoechea N, Baslam M, Erice G, Irigoyen JJ (2014) Increased photosynthetic acclimation in alfalfa associated with arbuscular mycorrhizal fungi (AMF) and cultivated in greenhouse under elevated $\mathrm{CO}_{2}$. J Plant Physiol 171:1774-1781. https://doi.org/10.1016/j.jplph.2014.07.027

26. Hajiboland R, Aliasgharzadeh N, Laiegh SF, Poschenrieder C (2010) Colonization with arbuscular mycorrhizal fungi improves salinity tolerance of tomato (Solanum lycopersicum L.) plants. Plant Soil 331:313-327. https://doi.org/10.1007/s11104-0090255-z

27. Heinemeyer A, Hartley IP, Evans SP, De La Fuente JAC, Ineson P (2007) Forest soil $\mathrm{CO}_{2}$ flux: uncovering the contribution and environmental responses of ectomycorrhizas. Glob Change Biol 13:1786-1797. https://doi.org/10.1111/j.1365-

2486.2007.01383.x

28. Hodge A, Campbell CD, Fitter AH (2001) An arbuscular mycorrhizal fungus accelerates decomposition and acquires nitrogen directly from organic material. Nature 413:297-299. https://doi.org/10.1038/35095041

29. Hoeksema JD, Chaudhary VB, Gehring CA, Johnson NC, Karst J, Koide RT, Pringle A, Zabinski C, Bever JD, Moore JC, Wilson GWT, Klironomos JN, Umbanhowar J (2010) A meta-analysis of context-dependency in plant response to inoculation with mycorrhizal fungi. Ecol Let 13:394-407. https://doi.org/10.1111/j.1461-0248.2009.01430.x

30. Högberg MN, Högberg P (2002) Extramatrical ectomycorrhizal mycelium contributes one-third of microbial biomass and produces, together with associated roots, half the dissolved organic carbon in a forest soil. New Phytol 154:791-795. https://doi.org/10.1046/j.1469-8137.2002.00417.x

31. Jakobsen I (1999) Mycorrhiza. Springer, Berlin

32. Jakobsen I, Abbott LK, Robson AD (1992) External hyphae of vesicular-arbuscular mycorrhizal fungi associated with Trifolium subterraneum L. New Phytol 120:371-380. https://doi.org/10.1111/j.1469-8137.1992.tb01077.xJakobsen I, Rosendahl L (1990) Carbon flow into soil and external hyphae from roots of mycorrhizal cucumber plants. New Phytol 115:77-83. https://doi.org/10.1111/j.1469-8137.1990.tb00924.x

33. Jansa J, Bukovská P, Gryndler M (2013) Mycorrhizal hyphae as ecological niche for highly specialized hypersymbionts or just soil free-riders? Front Plant Sci 4:134. https://doi.org/10.3389/fpls.2013.00134

34. Johnson NC, Graham JH, Smith FA (1997) Functioning of mycorrhizal associations along the mutualism-parasitism continuum. New Phytol 135:575-585. https://doi.org/10.1046/j.1469-8137.1997.00729.x

35. Jones CA (1983) A survey of the variability in tissue nitrogen and phosphorus concentrations in maize and grain sorghum. Field Crops Res 6:133-147. https://doi.org/10.1016/0378-4290(83)90053-9

36. Jones DL, Nguyen C, Finlay RD (2009) Carbon flow in the rhizosphere: carbon trading at the soil-root interface. Plant Soil 321:533. https://doi.org/10.1007/s11104-009-9925-0

37. Kaiser C, Kilburn MR, Clode PL, Fuchslueger L, Koranda M, John B. Cliff JB, Solaiman ZM, Murphy DV (2015) Exploring the transfer of recent plant photosynthates to soil microbes: mycorrhizal pathway vs direct root exudation. New Phytol 205:1537-1551.

https://doi.org/10.1111/nph.13138

Page $12 / 18$ 
38. Kardol P, Cornips NJ, van Kempen MM, Bakx-Schotman JT, van der Putten WH (2007) Microbe-mediated plant-soil feedback causes historical contingency effects in plant community assembly. Ecol Monogr 77(2):147-162. https://doi.org/10.1890/ 060502

39. Kiers ET, Duhamel M, Beesetty Y, Mensah JA, Franken O, Verbruggen E, Fellbaum CR, Kowalchuk GA, Hart MM, Bago A, Palmer TM, West SA, Vandenkoornhuyse P, Jansa J, Bücking H (2011) Reciprocal rewards stabilize cooperation in the mycorrhizal symbiosis. Science 333:880-882. https://doi.org/10.1126/science.1208473

40. Kirschbaum MU (2000) Will changes in soil organic carbon act as a positive or negative feedback on global warming? Biogeochemistry 48(1):21-51. https://doi.org/10. 1023/A:1006238902976

41. Klein T, Siegwolf RT, Körner C (2016) Belowground carbon trade among tall trees in a temperate forest. Science 352:342-344. https://doi.org/10.1126/science.aad6188

42. Klironomos JN (2003) Variation in plant response to native and exotic arbuscular mycorrhizal fungi. Ecology 84:2292-2301. https://doi.org/10.1890/02-0413

43. Kuzyakov Y, Cheng W (2004) Photosynthesis controls of $\mathrm{CO}_{2}$ efflux from maize rhizosphere. Plant Soil 263(1):85-99. https://doi.org/10.1023/B:PLSO.0000047728.61591.fd

44. Latef AAHA, Huang CX (2011) Effect of arbuscular mycorrhizal fungi on growth, mineral nutrition, antioxidant enzymes activity and fruit yield of tomato grown under salinity stress. Sci Hortic 127:228-233. https://doi.org/10.1016/j.scienta.2010.09.020

45. Leach KA, Braun DM (2016) Soluble sugar and starch extraction and quantification from maize (Zea mays) leaves. Curr Protoc Plant Biol 1:139-161. https://doi.org/10.1002/cppb.20018

46. Leake J, Johnson D, Donnelly D, Muckle G, Boddy L, Read D (2004) Networks of power and influence: the role of mycorrhizal mycelium in controlling plant communities and agroecosystem functioning. Can J Bot 82:1016-1045. https://doi.org/10.1139/b04-060

47. Lee BR, Muneer S, Avice JC, Jung WJ, Kim TH (2012) Mycorrhizal colonisation and P-supplement effects on N uptake and N assimilation in perennial ryegrass under well-watered and drought-stressed conditions. Mycorrhiza 22:525-534. https://doi.org/10.1007/s00572-012-0430-6

48. Lendenmann M, Thonar C, Barnard RL, Salmon Y, Werner RA, Frossard E, Jansa J (2011) Symbiont identity matters: carbon and phosphorus fluxes between Medicago truncatula and different arbuscular mycorrhizal fungi. Mycorrhiza 21(8):689-702. https://doi.org/10.1007/s00572-011-0371-5

49. Li XL, George E, Marschner H (1991) Extension of the phosphorus depletion zone in VA-mycorrhizal white clover in a calcareous soil. Plant Soil 136:41-48. https://doi.org/10.1007/BF02465218

50. Ling Q, Huang W, Jarvis P (2011) Use of a SPAD-502 meter to measure leaf chlorophyll concentration in Arabidopsis thaliana. Photosyn Res 107:209-214. https://doi.org/10.1007/s11120-010-9606-0

51. Liu Y, Miao HT, Chang X, Wu GL (2019) Higher species diversity improves soil water infiltration capacity by increasing soil organic matter content in semiarid grasslands. Land Degrad Dev 30(13):1599-1606. https://doi.org/10.1002/ldr.3349

52. Malhi Y, Doughty C, Galbraith D (2011) The allocation of ecosystem net primary productivity in tropical forests. Phil Trans R Soc B 366:3225-3245. https://doi.org/10.1098/rstb.2011.0062

53. Mariotte P, Mehrabi Z, Bezemer TM, De Deyn GB, Kulmatiski A, Drigo B, Veen CF, van der Heijden MGA, Kardol P (2018) Plant-soil feedback: bridging natural and agricultural sciences. Trends Ecol Evol 33(2): 129-142. https://doi.org /10.1016/j.tree.2017.11.005

54. Miller RM, Jastrow JD (2000) Mycorrhizal fungi influence soil structure. In: Koltai H, Kapulnik Y (eds) Arbuscular mycorrhizas: physiology and function. Springer, Berlin, pp 3-18

55. Miller RM, Kling M (2000) The importance of integration and scale in the arbuscular mycorrhizal symbiosis. Plant Soil 226:295309. https://doi.org/10.1023/A:1026554608366

56. Miller RM, Miller SP, Jastrow JD, Rivetta CB (2002) Mycorrhizal mediated feedbacks influence net carbon gain and nutrient uptake in Andropogon gerardii. New Phytol 155:149-162. https://doi.org/10.1046/j.1469-8137.2002.00429.x

57. Murphey JM, Powers JR, Spayd SE (1989) Estimation of soluble protein concentration of white wines using Coomassie brilliant blue G-250. Am J Enol Vitic 40:189-193. https://doi.org/10.1016/S0065-2164(08)70320-4

58. Nguyen TT, Cavagnaro TR, Thanh Ngo HT, Marschner P (2016) Soil respiration, microbial biomass and nutrient availability in soil amended with high and low C/N residue: Influence of interval between residue additions. Soil Biol Biochem 95:189-197.

https://doi.org/10.1016/j.soilbio.2015.12.020

Page 13/18 
59. Olsson PA, Rahm J, Aliasgharzad N (2010) Carbon dynamics in mycorrhizal symbioses is linked to carbon costs and phosphorus benefits. FEMS Microbiol Ecol 72:125-131. https://doi.org/10.1111/j.1574-6941.2009.00833.x

60. Parihar M, Rakshit A, Meena VS, Gupta VK, Rana K, Choudhary M, Tiwari G, Mishra PK, Pattanayak A, Bisht JK, Jatav SS, Khati P, Jatav HS (2020) The potential of arbuscular mycorrhizal fungi in C cycling: a review. Arc Microbiol 202:1581-1596. https://doi.org/10.1007/s00203-020-01915-x

61. Phillips JM, Hayman DS (1970) Improved procedures for clearing roots and staining parasitic and vesicular-arbuscular mycorrhizal fungi for rapid assessment of infection. Trans of the Br Mycol Soc 55:158-161. https://doi.org/10.1016/S00071536(70)80110-3

62. Řezáčová V, Konvalinková T, Jansa J (2017) Carbon fluxes in mycorrhizal plants. In Mycorrhiza-eco-physiology, secondary metabolites, nanomaterials (pp.1-21). Springer, Cham.

63. Řezáčová V, Slavíková R, Zemková L, Konvalinková T, Procházková V, Št́ovíček V, Hršelová $H$, Beskid O, Hujslová M, Gryndlerová H, Gryndler M, Püschel D, Jansa J (2018) Mycorrhizal symbiosis induces plant carbon reallocation differently in C3 and C4 Panicum grasses. Plant Soil 425(1):441-456. https://doi.org/10.1007/ s11104-018-3606-9

64. Rillig MC, Mummey DL (2006) Mycorrhizas and soil structure. New Phytol 171:41-53. https://doi.org/10.2307/3694482

65. Rocha-Nicoleite E, Overbeck GE, Müller SC (2017) Degradation by coal mining should be priority in restoration planning. Perspect Ecol Conserv 15(3):202-205. https://doi.org/10.1016/j.pecon.2017.05.006

66. Rodrigues K, Rodrigues B (2014) Arbuscular Mycorrhizal (AM) Fungi for sustainable Agriculture. In: Ghangaonkar NM (ed) Advances in Plant Sciences for sustainable Rural Development. C.T. Bora College, Shirur, pp 8-21

67. Scheublin TR, Sanders IR, Keel C, Van Der Meer JR (2010) Characterisation of microbial communities colonising the hyphal surfaces of arbuscular mycorrhizal fungi. ISME J 4:752-763. https://doi.org/10.1038/ismej.2010.5

68. Schlesinger WH (1999) Carbon Sequestration in Soils. Science 284:2095-2095. https://doi.org/10.1126/science.284.5423.2095

69. Schmedes A, Hølmer G (1989) A new thiobarbituric acid (TBA) method for determining free malondialdehyde (MDA) and hydroperoxides selectively as a measure of lipid peroxidation. J Am Oil Chem Soc 66:813-817. https://doi.org/10.1007/bf02653674

70. Sheng M, Tang M, Zhang F, Huang Y (2011) Influence of arbuscular mycorrhiza on organic solutes in maize leaves under salt stress. Mycorrhiza 21:423-430. https://doi.org/10.1007/s00572-010-0353-z

71. Shrestha RK, Lal R (2006) Ecosystem carbon budgeting and soil carbon sequestration in reclaimed mine soil. Environ Inter 32:781-796. https://doi.org/10.1016/j.envint.2006.05.001

72. Slavíková R, Püschel D, Janoušková M, Hujslová M, Konvalinková T, Gryndlerová H, Gryndler M, Weiser M, Jansa J (2017) Monitoring $\mathrm{CO}_{2}$ emissions to gain a dynamic view of carbon allocation to arbuscular mycorrhizal fungi. Mycorrhiza 27(1):35-51. https://doi.org/10.1007/s00572-016-0731-2

73. Smith SE, Read DJ (2010) Mycorrhizal symbiosis. Academic press,London

74. Smith NG, Dukes JS (2013) Plant respiration and photosynthesis in global-scale models: incorporating acclimation to temperature and $\mathrm{CO}_{2}$. Glob Chang Biol 19(1):45-63. https://doi.org/10.1111/j.1365-2486.2012.02797.x

75. Staddon PL, Ramsey CB, Ostle N, Philip Ineson P, Fitter AH (2003) Rapid turnover of hyphae of mycorrhizal fungi determined by AMS microanalysis of 14C. Science 300:1138-1140. https://doi.org/10.1126/science.1084269

76. Steinberg PD, Rillig MC (2003) Differential decomposition of arbuscular mycorrhizal fungal hyphae and glomalin. Soil Biol Biochem 35:191-194. https://doi.org/10.1016/S0038-0717(02)00249-3

77. Talaat NB, Shawky BT (2014) Modulation of the ROS-scavenging system in salt-stressed wheat plants inoculated with arbuscular mycorrhizal fungi. J Plant Nutri Soil Sci 177:199-207. https://doi.org/10.1002/jpln.201200618

78. Tisdall JM, Smith SE, Rengasamy P (1997) Aggregation of soil by fungal hyphae. Soil Res 35:55-60. https://doi.org/10.1071/S96065

79. Thomas RL, Sheard RW, Moyer JR (1967) Comparison of conventional and automated procedures for nitrogen, phosphorus, and potassium analysis of plant material using a single digestion. Agron J 59:240-243.

http://doi.org/10.2134/agronj1967.00021962005900030010x

80. Tomè E, Tagliavini M, Scandellari $F$ (2015) Recently fixed carbon allocation in strawberry plants and concurrent inorganic nitrogen uptake through arbuscular mycorrhizal fungi. J Plant Physiol 179:83-89. doi 10.1016/j.jplph.2015.02.008.

Page $14 / 18$ 
81. Toljander JF, Lindahl BD, Paul LR, Elfstrand M, Finlay RD (2007) Influence of arbuscular mycorrhizal mycelial exudates on soil bacterial growth and community structure. FEMS Microbiol Ecol 61:295-304. https://doi.org/10.1111/j.1574-6941.2007.00337.x

82. Treseder KK (2013) The extent of mycorrhizal colonization of roots and its influence on plant growth and phosphorus content. Plant Soil 371:1-13. https://doi.org/10.1007/s11104-013-1681-5

83. Vahter T, Bueno CG, Davison J et al (2020) Co-introduction of native mycorrhizal fungi and plant seeds accelerates restoration of post-mining landscapes. J Appl Ecol 57:1741-1751. https://doi.org/10.1111/1365-2664.13663

84. Van Der Heijden MG, Klironomos JN, Ursic M, Moutoglis P, Streitwolf-Engel R, Boller T, Wiemken A, Sanders IR (1998) Mycorrhizal fungal diversity determines plant biodiversity, ecosystem variability and productivity. Nature 396(6706):69-72. https://doi.org/10.1038/23932

85. Van der Putten WH, Bardgett RD, Bever JD, Bezemer TM, Casper BB, Fukami T, Kardol P, Klironomos JN, Schweitzer JA, Suding KN, van de Voorde TFJ, Wardle DA (2013) Plant-soil feedbacks: the past, the present and future challenges. J Ecol 101(2):265-276. https://doi.org/10.1111/1365-2745.12054

86. Veresoglou SD, Menexes G, Rillig MC (2012) Do arbuscular mycorrhizal fungi affect the allometric partition of host plant biomass to shoots and roots? A meta-analysis of studies from 1990 to 2010. Mycorrhiza 22:227-235. https://doi.org/10.1007/s00572011-0398-7

87. Wang F (2017) Occurrence of arbuscular mycorrhizal fungi in mining-impacted sites and their contribution to ecological restoration: Mechanisms and applications. Crit Rev Environ Sci Technol 47:1901-1957. https://doi.org/10.1080/10643389.2017.1400853

88. Wang G, Sheng L, Zhao D, Sheng JD, Wang XR, Liao H (2016) Allocation of nitrogen and carbon is regulated by nodulation and mycorrhizal networks in soybean/maize intercropping System. Front Plant Sci 7:1901. https://doi.org/10.3389/fpls.2016.01901

89. Wiesmeier M, Urbanski L, Hobley E, Lang B, Lützow M, Marin-Spiotta E, Wesemael B, Rabot E, Ließ M, Garcia-Franco N, Wollschläger U, Vogel HJ, Kögel-Knabner I (2019) Soil organic carbon storage as a key function of soils - A review of drivers and indicators at various scales. Geoderma 333:149-162. https://doi.org/10.1016/j.geoderma.2018.07.026

90. Wilschut RA, van der Putten WH, Garbeva P, Harkes P, Konings W, Kulkarni P, Martens H, Geisen S (2019) Root traits and belowground herbivores relate to plant-soil feedback variation among congeners. Nat commun 10(1):1-9. https:// doi.org/10.1038/s41467-019-09615-x

91. Wilson GWT, Rice CW, Rillig MC, Springer A, Hartnett DC (2009) Soil aggregation and carbon sequestration are tightly correlated with the abundance of arbuscular mycorrhizal fungi: results from long-term field experiments. Ecol Let 12:452-461. https://doi.org/10.1111/j.1461-0248.2009.01303.x

92. Wright SF, Upadhyaya A (1996) Extraction of an abundant and unusual protein from soil and comparison with hyphal protein of arbuscular mycorrhizal fungi. Soil Sci 161:575-586. https://doi.org/10.1097/00010694-199609000-00003

93. Xie Z-P, Staehelin C, Vierheilig H, Wiemken A, Jabbouri S, Broughton WJ, Vogeli-Lange R, Boller T (1995) Rhizobial nodulation factors stimulate mycorrhizal colonization of nodulating and nonnodulating soybeans. Plant Physiol 108:1519-1525. https://doi.org/10.1104/pp.108.4.1519

94. Yang G, Liu N, Lu W, Wang S, Kan HM, Zhang YJ, Xu L, Chen YL (2014) The interaction between arbuscular mycorrhizal fungi and soil phosphorus availability influences plant community productivity and ecosystem stability. J Ecol 102:1072-1082. https://doi.org/10.1111/1365-2745.12249

95. Zebec V, Rastija D, Lončarić Z, Bensa A, Popović B, Ivezić V V (2017) Comparison of chemical extraction methods for determination of soil potassium in different soil types. Euras Soil Sci 50:1420-1427. https://doi.org/10.1134/S1064229317130051

96. Zhang L, Shi N, Fan J, Wang F, George TS, Feng G (2018) Arbuscular mycorrhizal fungi stimulate organic phosphate mobilization associated with changing bacterial community structure under field conditions. Environ Microbiol 20:2639-2651. https://doi.org/10.1111/1462-2920.14289

97. Zhang L, Xu M, Liu Y, Zhang FS, Hodge A, Feng G (2016) Carbon and phosphorus exchange may enable cooperation between an arbuscular mycorrhizal fungus and a phosphate-solubilizing bacterium. New Phytol 210:1022-1032. https://doi.org/10.1111/nph.13838

98. Zhu YG, Miller RM (2003) Carbon cycling by arbuscular mycorrhizal fungi in soil-plant systems. Trends Plant Sci 8:407-409. https://doi.org/10.1016/S1360-1385(03)00184-5

Page 15/18 


\section{Figures}

(a)

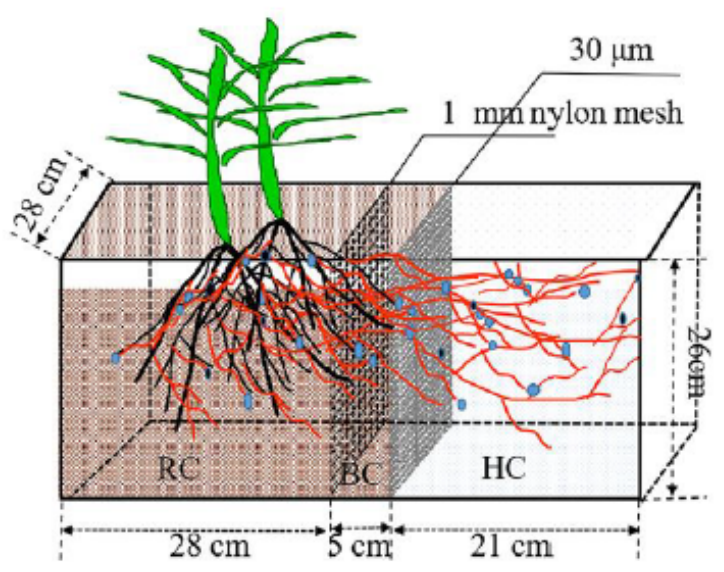

(b)

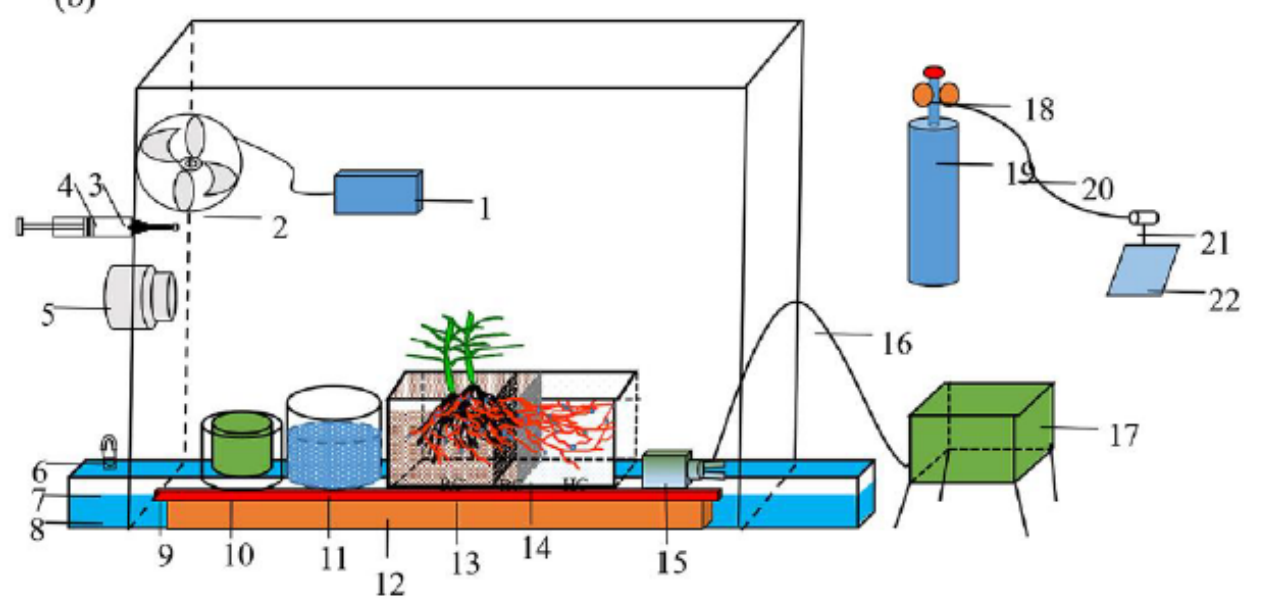

Figure 1

Schematic diagrams of (a) the three-compartment microcosm and (b) the pulse labeling device. RC, root compartment; BC, buffer compartment; $\mathrm{HC}$, hyphal compartment. One-mm nylon mesh was used to separate the RC and $\mathrm{BC}$ and $30 \mu \mathrm{m}$ nylon mesh was used to separate the $\mathrm{BC}$ and $\mathrm{HC}$. 1, rechargeable battery; 2 , electric fan; 3 , U-shaped silicone plug; 4, injector; 5 , semiconductor refrigerator; 6 , clip; 7, sink; 8, water; 9, plastic film; 10, thermometer; 11, silica gel; 12 , board; 13 , three-compartment microcosm; 14 , nylon mesh; 15 , LI6400 handheld probe; 16 , wire; 17, LI-6400 host; 18, pressure reducing valve; 19, $13 \mathrm{CO} 2$ cylinder; 20, plastic catheter; 21 , cock valve; 22 , vacuum bag. 

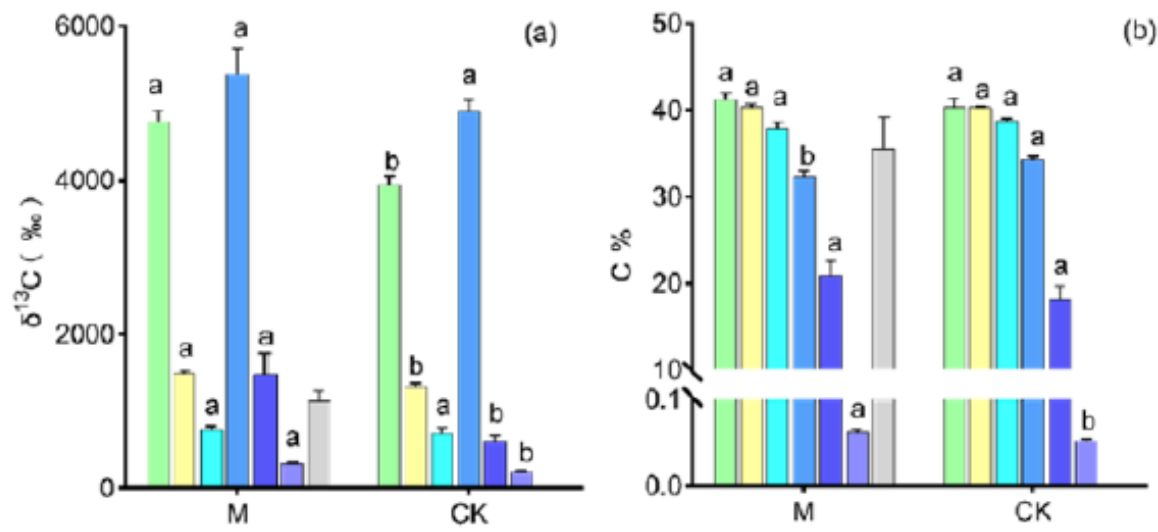

(b)
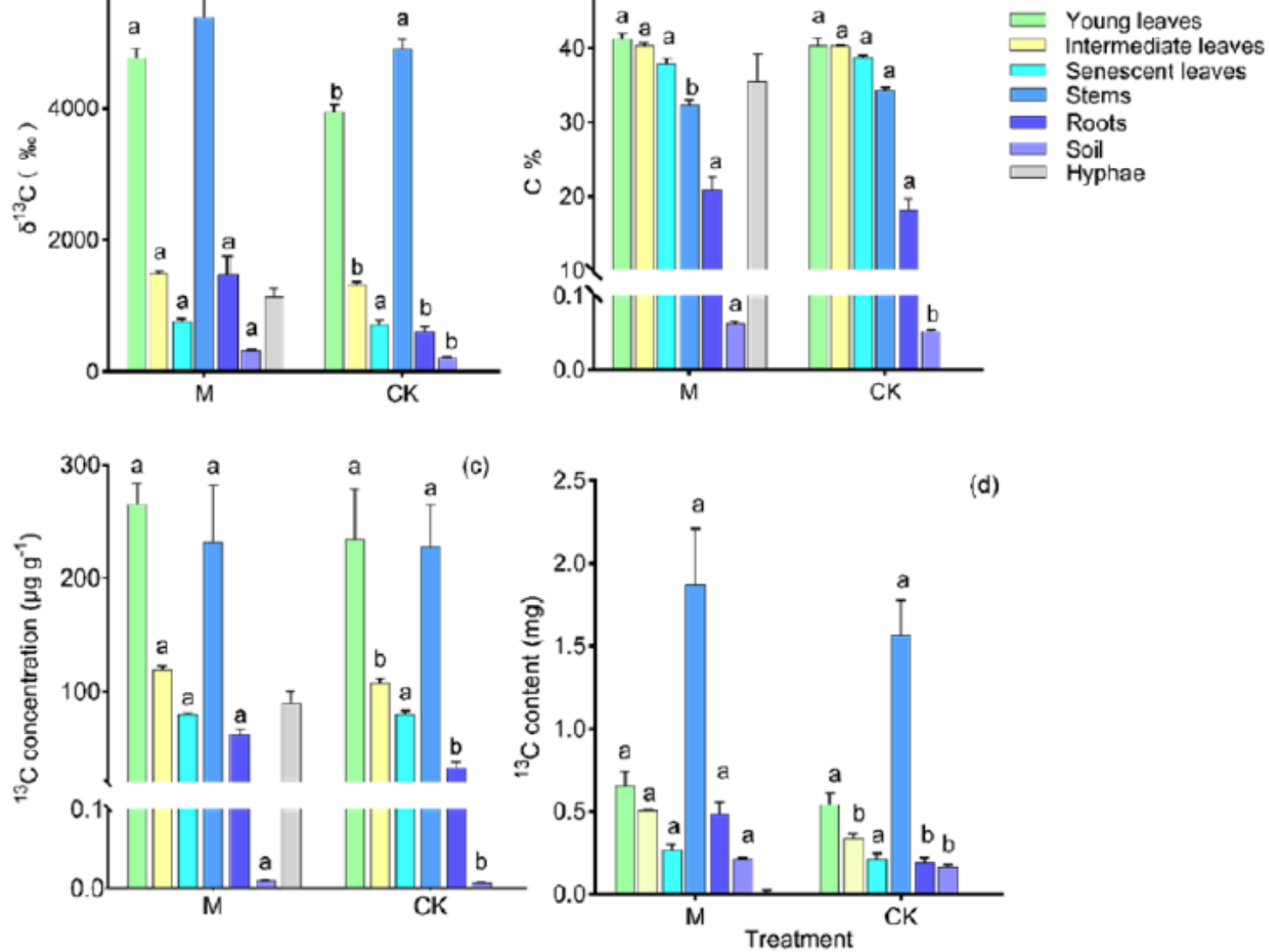

Figure 2

(a) $813 \mathrm{C},(\mathrm{b}) \mathrm{C} \%$, (c) $13 \mathrm{C}$ concentration and (d) 13C contents in different plant parts and the soil; M, mycorrhizal treatment; CK, nonmycorrhizal control; bars are mean values + standard errors $(n=3)$; different lowercase letters indicate a significant difference between mycorrhizal and non-mycorrhizal treatments at $\mathrm{P}<0.05$.



Young leaves

Intermediate leaves

$\square$ Senescent leaves

— Stems

- Roots

- Soil

Hyphae 


\section{Figure 3}

Distribution of $13 \mathrm{C}$ in different plant parts and the soil; bars are mean values + standard errors $(n=3)$; different lowercase letters indicate a significant difference between mycorrhizal and non-mycorrhizal treatments at $\mathrm{P}<0.05$.

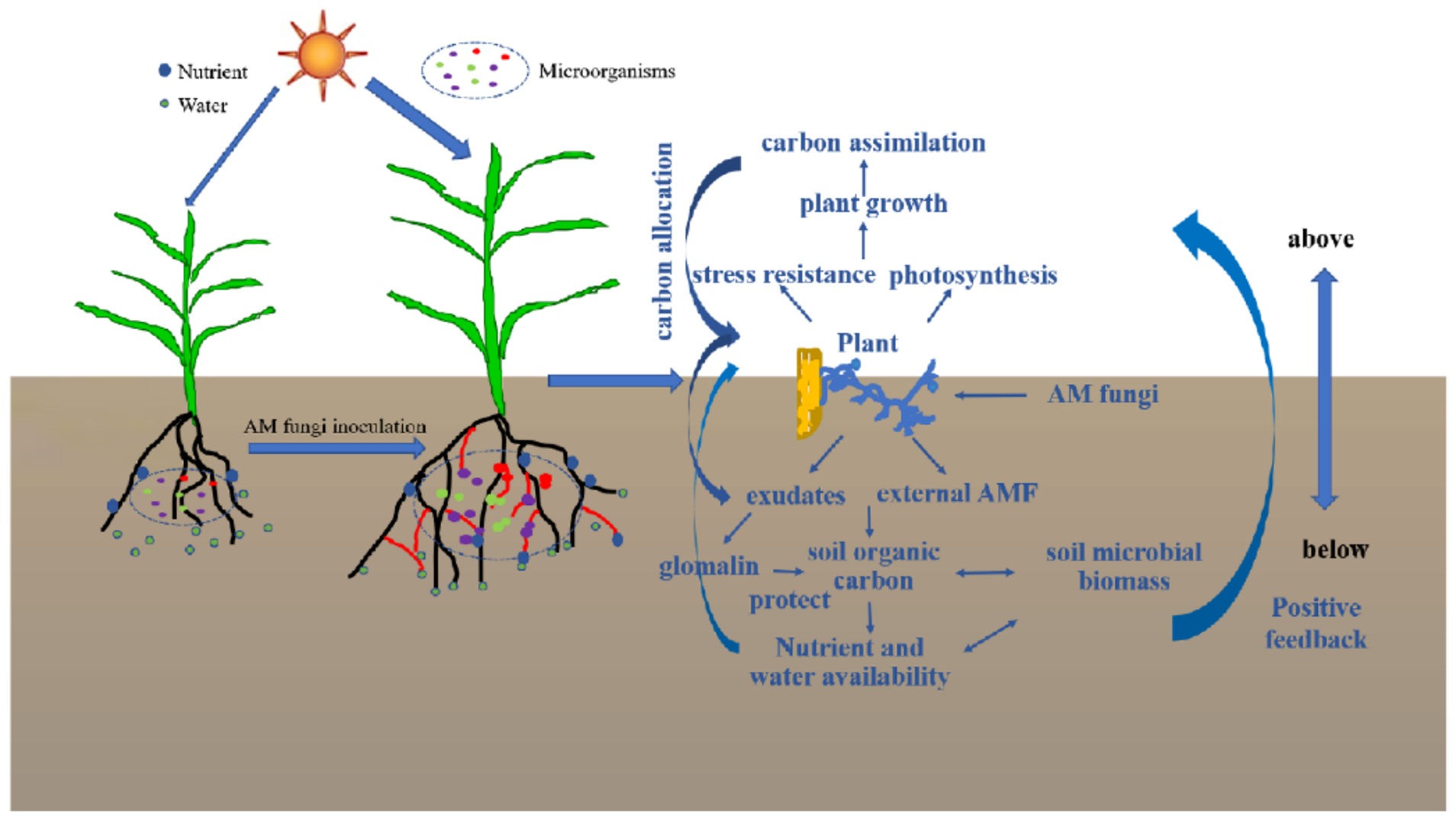

\section{Figure 4}

Schematic representation of increased above-belowground feedback through enhanced plant carbon assimilation and allocation. 